\title{
IMPLEMENTASI ALGORITMA A-STAR UNTUK PEMETAAN LOKASI SARANA KESEHATAN KABUPATEN MAJALENGKA BERBASIS GEOGRAPHIC INFORMATION SYSTEM (GIS)
}

\author{
Suhendri ${ }^{1}$, Dede Abdurahman ${ }^{2}$, Dani Irfan Maulana ${ }^{3}$ \\ ${ }^{1,2,3}$ Program Studi Informatika, Fakultas Teknik, Universitas Majalengka \\ Email: ${ }^{1}$ suhendri@unma.ac.id, ${ }^{2}$ dzildan@gmail.com, ${ }^{3}$ danirbc80@gmail.com
}

\begin{abstract}
ABSTRAK
Kabupaten Majalengka merupakan salah satu daerah Kabupaten dipropinsi Jawa Barat yang maju dan sangat pesat perkembangannya khususnya dalam bidang kesehatan. Dengan banyaknya pembangunan tempat kesehatan diberbagai kawasan yang ada di Kabupaten Majalengka, maka menjadi banyak pilihan bagi masyarakat untuk mendapatkan pelayanan kesehatan yang terbaik. Namun tidak sedikit dari masyarakat yang tidak mengetahui beberapa sarana kesehatan yang ada di Kabupaten Majalengka, kebanyakan masyarakat hanya mengetahui sarana kesehatan sekitar daerahnya, cara mencarinya masih harus bertanya kepada orang lain dan masyarakat belum mengetahui sarana kesehatan mana yang terdekat yang akan dituju. Karena kesehatan sangat penting bagi semua orang agar dapat produktif secara sosial maupun ekonomis.Dengan adanya hal tersebut, maka upaya dari hal tersebut adalah dengan memanfaatkan perkembangan teknologi informasi, untuk membuat sebuah aplikasi yang akan membantu masyarakat dalam menemukan lokasi sarana kesehatan terdekat. Hasil dari penelitian ini berupa sebuah aplikasi yang dapat memberikan informasi mengenai lokasi sarana kesehatan yang ada di Kabupaten Majalengka, yang dilengkapi dengan penunjuk jalan berupa maps yang telah diberikan algoritma A-Star untuk menentukan rute terdekat menuju lokasi atau sarana kesehatan.
\end{abstract}

Kata Kunci: Kabupaten Majalengka, Sarana Kesehatan, Sistem Informasi, Aplikasi, Algoritma A-Star.

\section{PENDAHULUAN}

\subsection{Latar Belakang}

Algoritma A-Star merupakan salah satu algoritma pencarian jarak yang memiliki kemampuan yang optimal dan komplit dalam memecahkan permasalahan yang berkaitan dengan pencarian atau penentuan sebuah rute dengan jarak terdekat.Secara konsep algoritma A-Star dibagi menjadi dua titik yaitu titik yang dapat dilalui atau biasa disebut dengan Open List dan titik yang tidak dapat dilalui atau biasa disebut dengan Close List. Secara fungsional, Close List berfungsi agar algoritma tersebut tidak melakukan pengecekan kembali pada titik yang telah dilaluinya sehingga proses pencarian yang dilakukan dapat berjalan lebih cepat dan mengurangi adanya proses pengecekan takterbatas pada tiap titik atau nodenya. Biasanya konsep pencarian rute terdekat pada sebuah algoritma adalah dimana algoritma tersebut akan berhenti jika tidak ada lagi Open List atau titik akhir sudah ditentukan.(Mutsaqov, Fernando, \& Megawaty, 2020).

Algoritma A-Star yang diterapkan pada aplikasi merupakan algoritma mencari lintasan terpendek berdasarkan graph ter-arah, yang mampu menemukan jalur dengan biaya pengeluaran (Cost) paling sedikit dari titik permulaan yang diberikan sampai ke titik tujuan yang diharapkan. Dengan diterapkannya Algoritma A-Star maka informasi sarana kesehatan dan jalur terdekat akan lebih akurat karena metode ini memilih sisi yang berbobot minimum. (Purnama, Megawaty, \& Fernando, 2018) Kelebihan algoritma ini yaitu meminimumkan total biaya lintasan, berbentuk kotak untuk mempermudah mencari lintasan terpendek, pada kondisi yang tepat algoritma AStar akan memberikan solusi yang terbaik dalam waktu yang optimal, namun algoritma A-Star ini mempunyai kekurangan nya, data yang dihasilkan masih kurang valid, dan kecepatan dalam memperoleh data masih dipengaruhi oleh nilai atau jarak pada simpul. Untuk menyajikan informasi rute terdekat dengan berbasis sistem informasi geografis agar memudahkan masyarakat dalam mencari lokasi sarana kesehatan.

Sistem Informasi Geografis (Geographic Information System disingkat GIS) adalah sistem informasi khusus yang mengelola data yang memiliki informasi spasial (bereferensi keruangan). Pengertian informasi geografis adalah informasi mengenai tempat atau lokasi, dimana suatu objek terletak di permukaan bumi dan informasi mengenai objek dimanalokasi geografis itu berada untuk dianalisa dalam pengambilan keputusan. Sistem informasi geografis merupakan sistem kompleks yang umumnya terintegrasi dengan sistem komputer lainnya ditingkat fungsional dan jaringan. (Nugroho \& Kusuma, 2018) Sistem Informasi Geografis ini akan digunakan sebagai aplikasi pencarian sarana kesehatan yang ada di Kabupaten Majalengka.

Kabupaten Majalengka merupakan salah satu daerah Kabupaten dipropinsi Jawa Barat yang maju dan sangat pesat perkembangannya khususnya dalam bidang kesehatan.Dengan banyaknya pembangunan tempat kesehatan diberbagai kawasan yang ada di Kabupaten Majalengka, maka menjadi banyak pilihan bagi masyarakat untuk 
mendapatkan pelayanan kesehatan yang terbaik.

Berdasarkan UU 36 tahun 2009 tentang Kesehatan menyatakan bahwa kesehatan adalah keadaan sehat, baik secara fisik, mental, spritual maupun sosial yang memungkinkan setiap orang untuk hidup produktif secara sosial dan ekonomis. Setiap orang berhak atas kesehatan.Oleh karena itu dibutuhkan wadah yang dapat memberikan informasi tentang sarana kesehatan yang ada di Kabupaten Majalengka.

Data sampel adalah sebagian atau wakil populasi yang akan diteliti. (Arikunto, 2010) Menurut data sample yang dihasilkan melalui wawancara 500 orang masyarakat desa Campaga, Majalengka, di ambil 10\% nya, masyarakat masih banyak yang belum mengetahui dimana saja lokasi sarana kesehatan yang ada di Majalengka,kebanyakan masyarakat hanya mengetahui sarana kesehatan sekitar daerahnya,cara mencarinya masih harus bertanya kepada orang lain dan masyarakat belum mengetahui sarana kesehatan mana yangterdekat yang akan dituju. Karena kesehatan sangat penting bagi semua orang agar dapat produktif secara sosial maupun ekonomis.

Dengan demikian masyarakat harus mendapatkan informasi tentang sarana kesehatan yang ada di Kabupaten Majalengka.Namun informasi lokasi sarana kesehatan dan rute terdekat yang dibutuhkan oleh para masyarakat belum ada di Kabupaten Majalengka.

Belum adanya sistem informasi tentang sarana kesehatan yang ada di Kabupaten Majalengka membuat penulis berinisiatif untuk membuat wadah untuk memberikan informasi kepada masyarakat tentang lokasi sarana kesehatan yang ada di Kabupaten Majalengka.

Di era digital saat ini informasi sangat mudah kita berikan dan dapatkan baik itu dari media sosial, blog, artikel web dan lain-lain. Dengan kemudahan itu penulis berinisiatif untuk membuat sebuah sistem informasi berbasis Sistem Informasi Geografis (Geographic Information System disingkat GIS) yang dapat menjadi wadah untuk informasi lokasi sarana kesehatan yang ada di Kabupaten Majalengka, agar memudahkan masyarakat dalam mengaksesnya.

Aplikasi yang akan dibuat dalam pencarian lokasi dan rute terdekat ini menggunakan Algoritma AStar dengan bantuan google Maps API untuk memetakan lokasi sarana kesehatan, masyarakat mengakses aplikasi melalui smartphone android yang sudah terkoneksi dengan internet dan GPS (Global Positioning System) untuk mencari sarana kesehatan.

\section{LANDASAN TEORI 2.1. Algoritma A-Star}

Algoritma A-Star merupakan salah satu algoritma pencarian jarak yangmemiliki kemampuan yang optimal dan komplit dalam memecahkan permasalahan yang berkaitan dengan pencarian atau penentuan sebuah rute dengan jarak terdekat.Secara konsep algoritma $A$-Star dibagi menjadi dua titik yaitu titik yang dapat dilalui atau biasa disebut dengan Open List dan titik yang tidak dapat dilalui atau biasa disebut dengan Close List. Secara fungsional, Close List berfungsi agar algoritma tersebut tidak melakukan pengecekan kembali pada titik yang telah dilaluinya sehingga proses pencarian yangdilakukan dapat berjalan lebih cepat dan mengurangi adanya proses pengecekan tak terbatas pada tiap titik atau nodenya. Biasanya konsep pencarian rute terdekat pada sebuah algoritma adalah dimana algoritma tersebut akan berhenti jika tidak ada lagi Open List atau titik akhir sudah ditentukan. Penulis berharap dengan diterapkannya algoritma A-Star dalam aplikasi pencarian sarana kesehatan ini, dapat memberikan informasi mengenai jarak danatau jalur terdekat yang akurat dan sesuai dengan apa yang dibutuhkan oleh penggunanya. (Mutsaqov, Fernando, \& Megawaty, 2020)

\subsection{Pengertian Pemetaan}

Pemetaan adalah proses, cara, perbuatan membuat peta. Petaadalah gambar atau lukisan pada kertas dan sebagainya yang menunjukkan letak tanah, laut, sungai, gunung, dan sebagainya, representasi melalui gambar dari suatu daerah yang menyatakan sifat, seperti batas daerah, sifat permukaan; denah.(Lingga Wijaya, 2017)

\subsection{Sarana Kesehatan}

Sarana Kesehatan adalah tempat yang digunakan untuk menyelenggarakan upaya kesehatan.Dan Kesehatan adalah sesuatu yang sangat berguna bagi kita semua, karena kesehatan adalah modal dasar bagi setiap orang untuk melakukan segala aktivitas dengan baik dan maksimal.

\subsection{Sistem Informasi Geografis (Geographic Information System disingkat GIS)}

Sistem Informasi Geografis (Geographic Information System disingkat GIS) adalah sistem informasi khusus yang mengelola data yang memiliki informasi spasial (bereferensi keruangan). Pengertian informasi geografis adalah informasi mengenai tempat atau lokasi, dimana suatu objek terletak di permukaan bumi dan informasi mengenai objek dimana lokasi geografis itu berada untuk dianalisa dalam pengambilan keputusan. Sistem informasi geografis merupakan sistem kompleks yang umumnya terintegrasi dengan sistem komputer lainnya ditingkat fungsional dan jaringan (Nugroho \& Kusuma, 2018). 


\section{METODOLOGI PENELITIAN 3.1. Kerangka Penelitian}

Untuk memudahkan pemahaman tahap-tahap yang dilakukan oleh peneliti tugas akhir maka dibuatlah kerangka penelitian. Kerangka penelitian tugas akhir dapat dilihat pada gambar 3.1

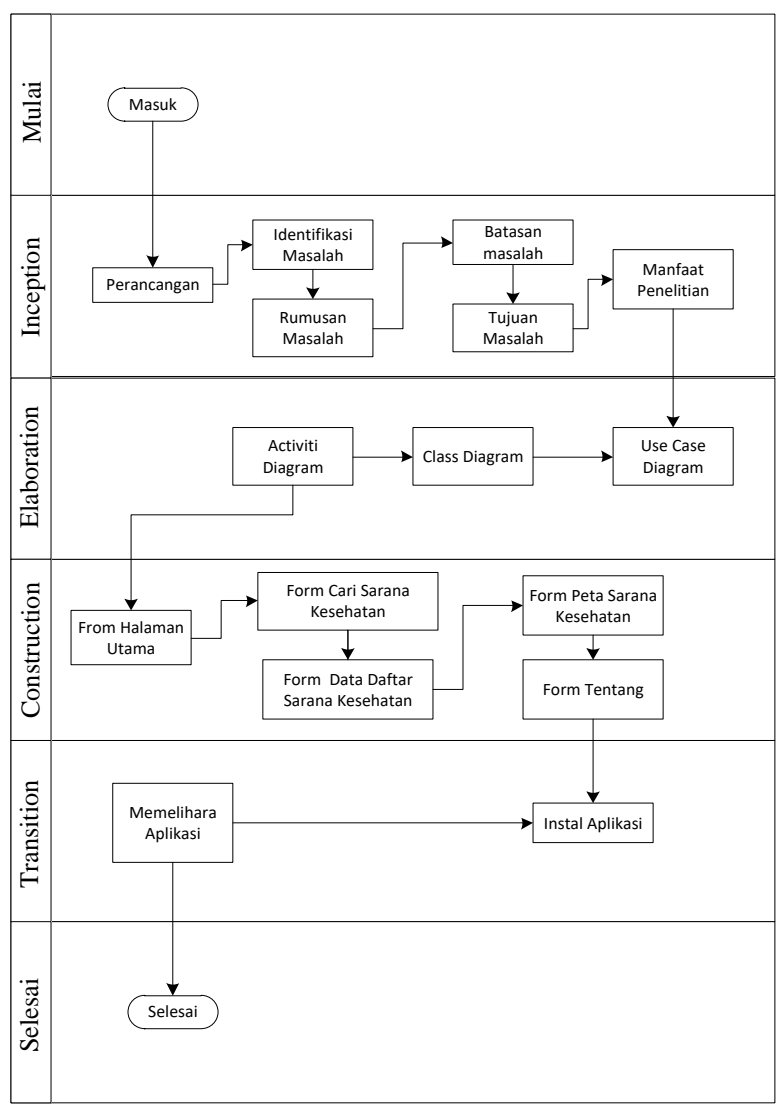

Gambar 1. Kerangka Penelitian

\subsection{Pengumpulan Data}

Dalam pengumpulan data dilakukan dengan 2 (dua) metode yaitu.

\subsubsection{Metode Lapangan (Field Research)}

Metode ini dilakukan secara langsung dengan mengumpulkan data yang berhubungan dengan implementasi algoritma a-star untuk pemetaan lokasi sarana kesehatan Kabupaten Majalengka. Pengumpulan data dilakukan dengan cara sebagai berikut.

1. Observasi (Pengamatan Langsung)

Pengamatan langsung dilakukan dengan cara mendatangi objek yang akan dikaji dalam pembuatan aplikasi sarana kesehatan dan aspek lainnya saat observasi.

2. Interview(wawancara)

Pada tahap ini penulis melakukan interview (wawancara) kepada masyarakat tentang lokasi sarana kesehatan yang ada di Majalengka.Untuk mendapatkan penjelasan tentang lokasi sarana kesehatan.

\subsubsection{Metode Perpustakaan (Library Research)}

Dalam metode ini penulis mengutip dari beberapa bacaan yang berkaitan denganalgoritma a-star dan pemetaan lokasi.Yang dikutip dapat berupa teori ataupun beberapa pendapat dari beberapa buku bacaan dan buku diktat yang dipergunakan selama kuliah.Ini dimaksudkan untuk memberikan landasan teori yang kuat melalui buku-buku atau literatur yang tersedia di perpustakaan.

\subsection{Analisis Sistem Yang Sedang Berjalan}

Sistem yang berjalan pada penelitian ini, proses sistem yang sedang berjalan pada pencarian lokasi sarana kesehatan masih menggunakan cara harus bertanya kepada orang lain, bertanya kepada saudara, dan searching ke internet.

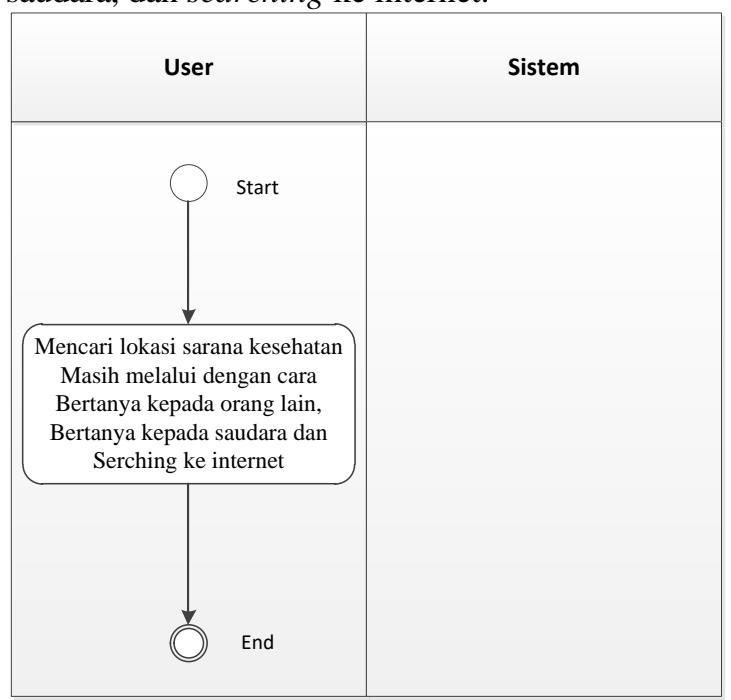

Gambar 2. Analisis Sistem Yang Sedang Berjalan

\subsection{Analisis Sistem Yang Diusulkan}

Sistem yang akan diusulkan yaitu sebuah aplikasi sarana kesehatan aplikasi ini untuk mencari lokasi sarana kesehatan terdekat yang ada di Kabupaten Majalengka.

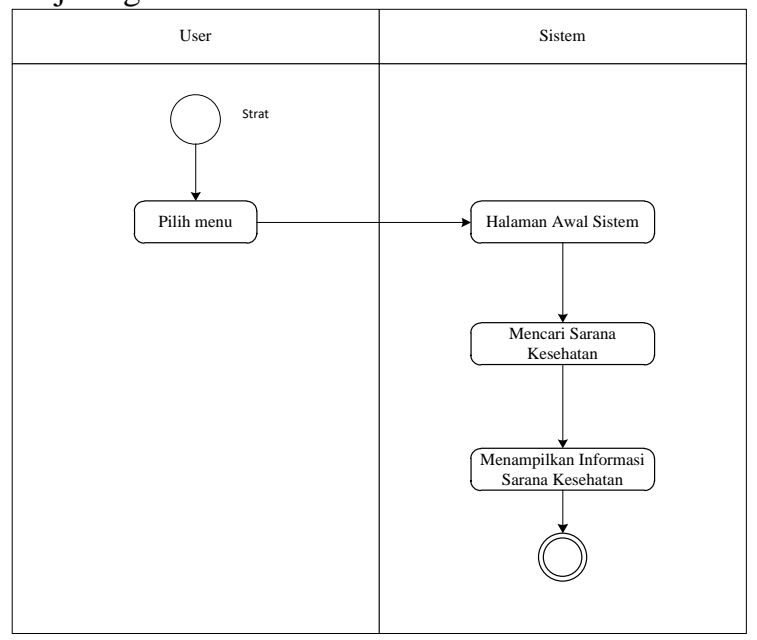

Gambar 3. Analisis Sistem Yang Diusulkan 


\subsection{Flowchart}

Flowchart sistem dalam penelitian ini pula dirancang sebuah flowchart alur sistem, yang mana pada akhirnya program yang dirancang dapat dengan mudah dibuat dan diaplikasikan dalam phone cell. Adapun flowchart sistemnya.

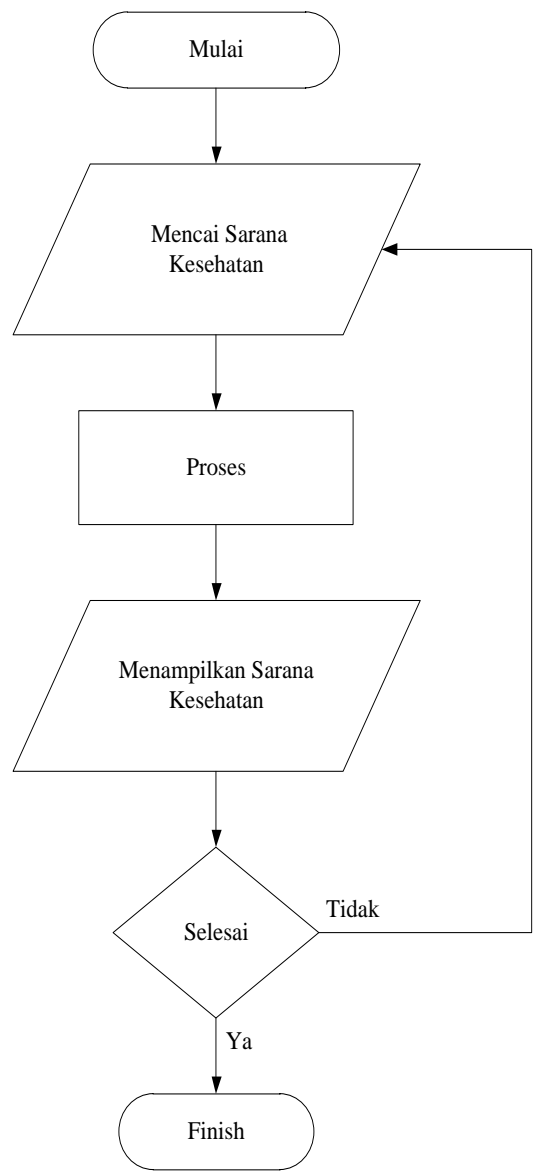

Gambar 4. Flowchart

\subsection{Analisis Algoritma A-Star}

Algoritma A-Star adalah algoritma Best First Search yang merupakan perpaduan antara Uniform Cost Search dan Greedy-Best First Search. Uniform Cost Search ini akan memilih jarak paling kecil dari simpul awal ke simpul berikutnya sampai ke simpul tujuan, sedangkan Greedy-Best First Search yang menggunakan fungsi heuristik akan memperkirakan biaya dari simpul awal ke simpul tujuan. Heuristik ini memiliki peran yang sangat penting untuk mengontrol pencarian pada algoritma A*, sehingga algoritma ini akan menemukan rute yang complete (selalu menemukan solusi) dan optimal.

Algoritma $A^{*}$ secara garis besar dapat dijelaskan seperti berikut:

1. Masukkan node awal ke openlist

2. Loop langkah-langkah dibawah ini: a. Cari node (n) dengan nilai $\mathrm{f}(\mathrm{n})$ yang paling kecil dalam open list, dan node ini sekarang menjadi current node.

b. Keluarkan current node dari openlist dan masukkan ke open list

c. Untuk setiap tetangga dari current node lakukan berikut

1) Jika tidak dapat dilalui atau sudah ada dalam close list, abaikan.

2) Jika belum ada di open list buat current node parent dari node tetangga ini, simpan nilai $\mathrm{f}, \mathrm{g}$, dan $\mathrm{h}$ dari node ini.

3) Jika sudah ada di openlist cek apabila node tetangga ini lebih baik menggunakan nilai g sebagai ukuran. Jika lebih baik ganti parent dari node ini di opentlist menjadi current node, lalu kalkulasikan ulang nilai $\mathrm{g}$ dan $\mathrm{f}$ dari node ini.

d. Hentikan looping jika:

1) Node tujuan telah ditambah ke openlist yang berarti rute ditemukan

2) Belum menemukan node akhir (tujuan) sementara openlist kosong atau berarti tidak ada rute.

Simpan rute, lalu secara backward urut mulai dari node akhir (tujuan) sampai ke titik awal sambil menyimpan node ke dalam array.

Analisis algoritma A-Star ini dirancang sketsa peta dan rute, yang mana pada akhirnya program yang dirancang dapat dengan mudah dibuat dan diaplikasikan dalam phone cell. Adapun analisis algoritma bias dilihat dibawah ini.

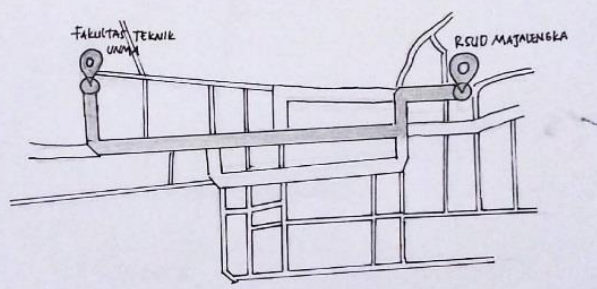

Gambar 5. Analisis Algoritma A-Star

\subsubsection{Pembuatan Graph}

Peneliti melakukan Pembuatan Graph atau titik-titik node dilakukan untuk membuat dasar jalur yang dapat dilalui menuju lokasi terkait.Dapat dilihat pada gambar berikut, terdapat beberapa titik titik node yang saling terhubung satu dengan yang lainnya.kemudian akan diambil nilai Latitude dan Longitude -nya untuk disimpan kedalam database. 
Semakin banyak pembuatan titik node maka akan semakin akurat jarak estimasi dari titik awal ke titik tujuan.

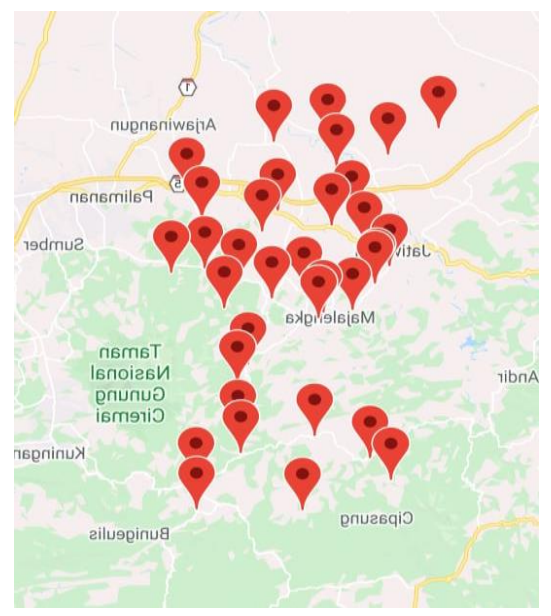

Gambar 6. Graph Sarana Kesehatan

\subsubsection{Peta Matriks}

Pada peta matriks diatas terdapat dua parameter berbeda yaitu, warna hijau melambangkan Node persimpangan yang dilalui, warna biru merupakan titik awal (SMKN 1 Majalengka), dan titik berwarna orange merupakan titik tujuan (UPTD Puskesmas Majalengka).

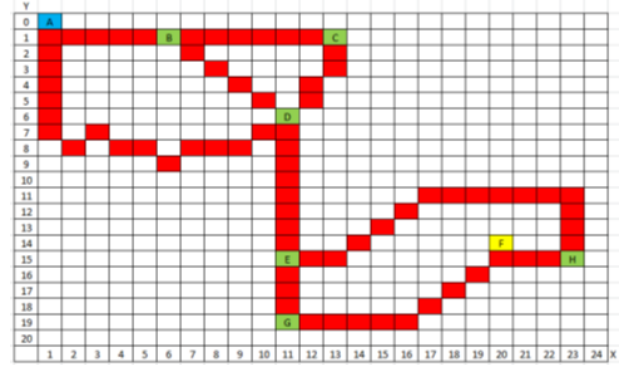

Gambar 7. Peta Matriks

\subsubsection{Pemilihan Rute}

Node start di notasikan dengan huruf A sedangkan node goals di notasikan dengan huruf $\mathrm{F}$, sedangkan huruf lainnya merupakan persimpangan dari node $\mathrm{A}$ ke node $\mathrm{F}$.

Tabel 1. Opsi Pemilihan Rute

\begin{tabular}{|l|l|l|}
\hline Rute & Path / Node & Jalan yang dipilih \\
\hline \multirow{2}{*}{1} & A-D-E-H-F & $\begin{array}{l}\text { Jl. Cicenang - Jl. KH.Adul } \\
\text { Halim }- \text { Jl. Gerakan } \\
\text { Koperasi }- \text { Jl. Ahmad } \\
\text { Kusumah }\end{array}$ \\
\hline 2 & A-D-E-G-F & $\begin{array}{l}\text { Jl. Cicenang - Jl. KH.Adul } \\
\text { Halim - Jl. Ahmad } \\
\text { Kusumah }\end{array}$ \\
\hline 3 & $\begin{array}{l}\text { Jl. Jatiwangi Majalengka - } \\
\text { Jl. Raya Laswi - Jl. } \\
\text { KH.Adul Halim - Jl. } \\
\text { Gerakan Koperasi - Jl. } \\
\text { Ahmad Kusumah }\end{array}$ \\
\hline
\end{tabular}

\begin{tabular}{|l|l|l|}
\hline Rute & Path / Node & Jalan yang dipilih \\
\hline 4 & $\begin{array}{l}\text { A-B-D-E-G- } \\
\text { F }\end{array}$ & $\begin{array}{l}\text { Jl. Jatiwangi Majalengka - } \\
\text { Jl. Raya Laswi - Jl. } \\
\text { KH.Adul Halim - J1. } \\
\text { Ahmad Kusumah }\end{array}$ \\
\hline 5 & $\begin{array}{l}\text { A-B-C-D-E- } \\
\text { H-F }\end{array}$ & $\begin{array}{l}\text { Jl. Jatiwangi Majalengka - KH.Adul Halim - Jl. } \\
\text { Jerakan Koperasi - Jl. } \\
\text { Ahmad Kusumah }\end{array}$ \\
\hline 6 & $\begin{array}{l}\text { A-B-C-D-E- } \\
\text { G-F }\end{array}$ & $\begin{array}{l}\text { Jl. Jatiwangi Majalengka - } \\
\text { Jl. KH.Adul Halim - Jl. } \\
\text { Ahmad Kusumah }\end{array}$ \\
\hline
\end{tabular}

Berikut adalah koordinat yang didapat dari setiap node-nya, dapat dilihat pada tabel 2.

Tabel 2. Koordinat pada Node

\begin{tabular}{|l|l|}
\hline Titik / Node & Koordinat \\
\hline A & $(1,0)$ \\
\hline B & $(6,1)$ \\
\hline C & $(13,1)$ \\
\hline D & $(11,6)$ \\
\hline E & $(11,15)$ \\
\hline F & $(20,14)$ \\
\hline G & $(11,19)$ \\
\hline H & $(23,15)$ \\
\hline
\end{tabular}

Setelah menentukan titik korrdinat maka setiap node dicatat jarak yang kemudian digunakan untuk memperoleh rute yang paling cepat atau terbaik atau paling optimal dari semua opsi rute yang dapat dilalui. Pada prosesnya perhitungan dilakukan dengan menggabungkan fungsi heuristic pada setiap node-nya. Jarak antar node dapat dilihat pada tabel berikut.

Tabel 3. Jarak Antar Node

\begin{tabular}{|l|l|}
\hline Node & Jarak \\
\hline A-B & $714 \mathrm{M}$ \\
\hline B-C & $578 \mathrm{M}$ \\
\hline C-D & $704 \mathrm{M}$ \\
\hline A-D & $1700 \mathrm{M}$ \\
\hline B-D & $656 \mathrm{M}$ \\
\hline D-E & $751 \mathrm{M}$ \\
\hline E-G & $305 \mathrm{M}$ \\
\hline E-H & $1100 \mathrm{M}$ \\
\hline G-F & $726 \mathrm{M}$ \\
\hline H-F & $333 \mathrm{M}$ \\
\hline
\end{tabular}

Urutan tahap selanjutnya adalah melakukan perhitungan pada fungsi Heuristik. Fungsi Heuristik yang penulis gunakan untuk melakukan perhitungan adalah nilai Heuristik Euclidean Distance. Nilai HED dapat memberikan hasil pencarian rute yang lebih baik atau hampir mendekati jarak sesungguhnya. 
Setelah diketahui nilai Heuristic pada setiap rute yang terbentuk, tahapan selanjutnya adalah peneliti melakukan proses perhitungan menggunakan rumus algoritma A-Star untuk menentukan rute terdekat atau rute teroptimal dari titik awal ke titik tujuan dengan menggunakan rumus algoritma A-Star. Berikut adalah hasil dari perhitungan secara keseluruhan dari setiap node:

a Pada rute dengan node "A-D-E-H-F", menghasilkan nilai total dari $\mathrm{f}(\mathrm{n})$ adalah sebesar $3.884 \mathrm{~m}$

b Pada rute dengan node "A-D-E-G-F", menghasilkan nilai total dari $\mathrm{f}(\mathrm{n})$ adalah sebesar $3.482 \mathrm{~m}$

c Pada rute dengan node "A-B-D-E-H-F", menghasilkan nilai total dari $\mathrm{f}(\mathrm{n})$ adalah sebesar $3.554 \mathrm{~m}$

d Pada rute dengan node "A-B-D-E-G-F", menghasilkan nilai total dari $\mathrm{f}(\mathrm{n})$ adalah sebesar $3.152 \mathrm{~m}$

e Pada rute dengan node "A-B-C-D-E-H-F", menghasilkan nilai total dari $\mathrm{f}(\mathrm{n})$ adalah sebesar $4.180 \mathrm{~m}$

f Pada rute dengan node "A-B-C-D-E-G-F", menghasilkan nilai total dari $\mathrm{f}(\mathrm{n})$ adalah sebesar $3.778 \mathrm{~m}$

Setelah dilakukan proses perhitungan menggunakan rumus algoritma A-Star diatas dengan notasi rute yang berbeda, maka penulis menarik kesimpulan bahwa hasil perhitungan rute terdekat dari titik awal ke titik tujuan memiliki nilai teroptimal pada rute bernotasi "A - B - D - E - G - F" dengan bobot total $\mathrm{f}(\mathrm{n})$ adalah $3.152 \mathrm{~m}$.Kemudian penulis membandingkan kesesuaian antara pencarian rute terdekatsecara manual dan dengan menggunakan sistem atau aplikasi. Berikut adalah tampilan hasil pemilihan rute yang dilakukan oleh sistem

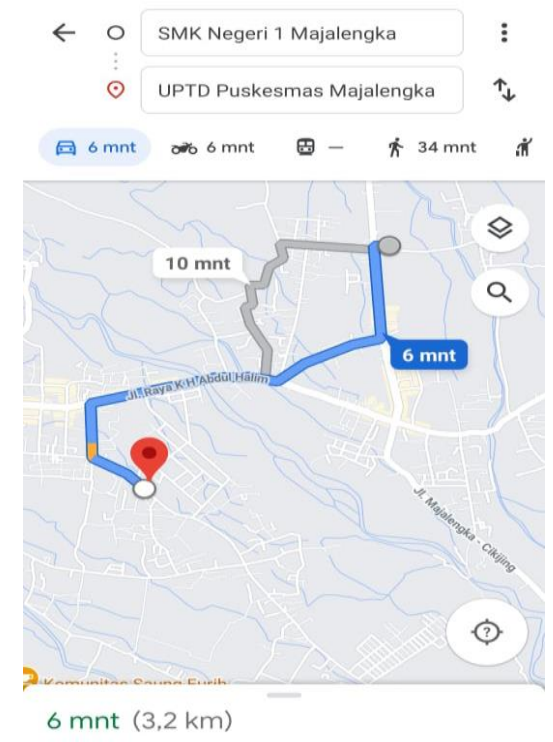

Gambar 8. Hasil Pencarian Rute Pada Aplikasi
Pada gambar diatas, aplikasi menentukan jarak yang sama dengan proses perhitungan jalur secara manual yaitu dengan melewati jalan Jl. Cicenang Jl. KH.Adul Halim - Jl. Ahmad Kusumah. Pada percobaan perhitungan manual, hasil yang diberikan adalah sebesar $3.152 \mathrm{~m}$, sedangkan pada percobaan yang dilakukan di aplikasi menghasilkan nilai jarak sebesar 3200 meter dari titik awal ke titik tujuan dengan rute atau node yang sama dengan perbedaan jarak sebesar 48 meter.

\section{PEMBAHASAN}

\subsection{Use Case Diagram}

Use case diagram adalah diagram use case yang digunakan untuk menggambarkan secara ringkas siapa saja yang menggunakan sisem dan apa saja yang bisa dilakukan. Diagram usecase tidak bisa menjelaskan secara detail tentang pengunaan use case, namun hanya memberikan gambaran singkat hubungan antara use case, aktor, dan sistem. Melalui diagram use case dapat diketahui fungsi fungsi apa saja yang ada pada sistem aplikasi pemetaan lokasi sarana kesehatan berbasis android. Namun suatu use case harus didefinisikan semudah mungkin dan dapat dipahami.

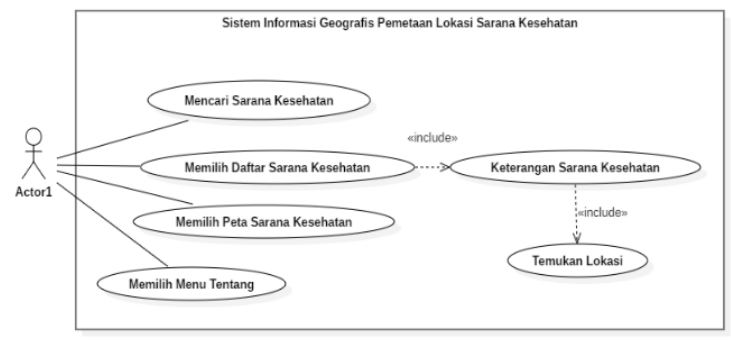

Gambar 9. Usecase Diagram Pemetaaan Lokasi Sarana Kesehatan

\subsection{Activity Diagram}

Activity diagram menggambarkan penggunaan aplikasi pemetaaan lokasi sarana kesehatan berbasis android yang dirancang, dibuat berdasarkan form form yang terdapat didalam aplikasi, berikut gambar activity diagram yang di rancang. 


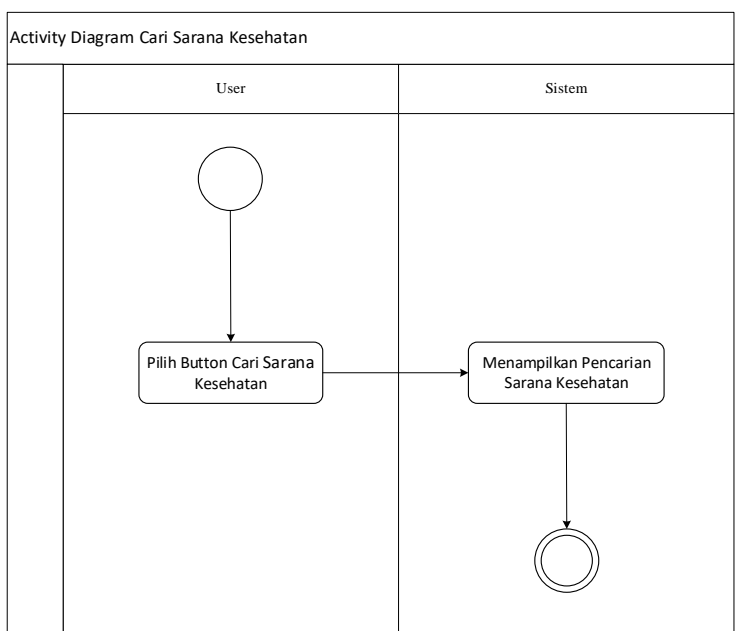

Gambar 10. Activity Diagram Cari Sarana Kesehatan

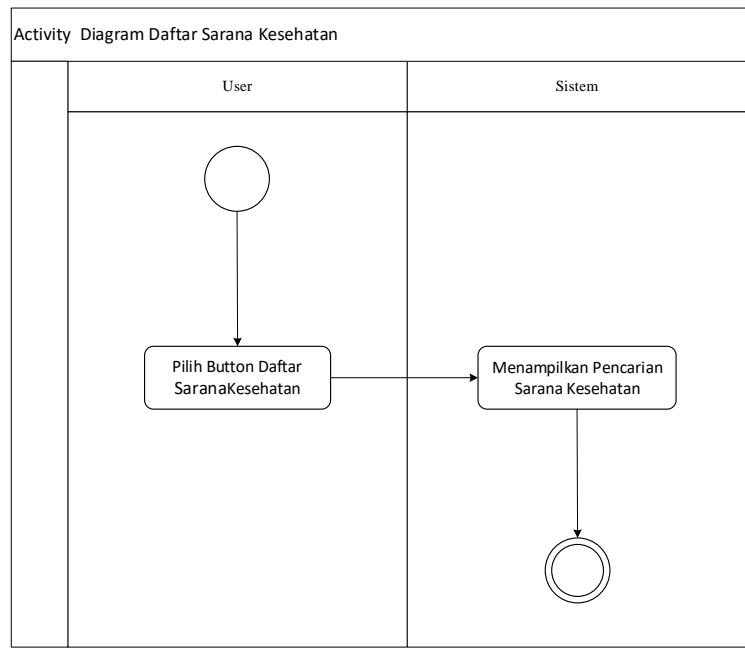

Gambar 11. Activity Diagram Daftar Sarana Kesehatan

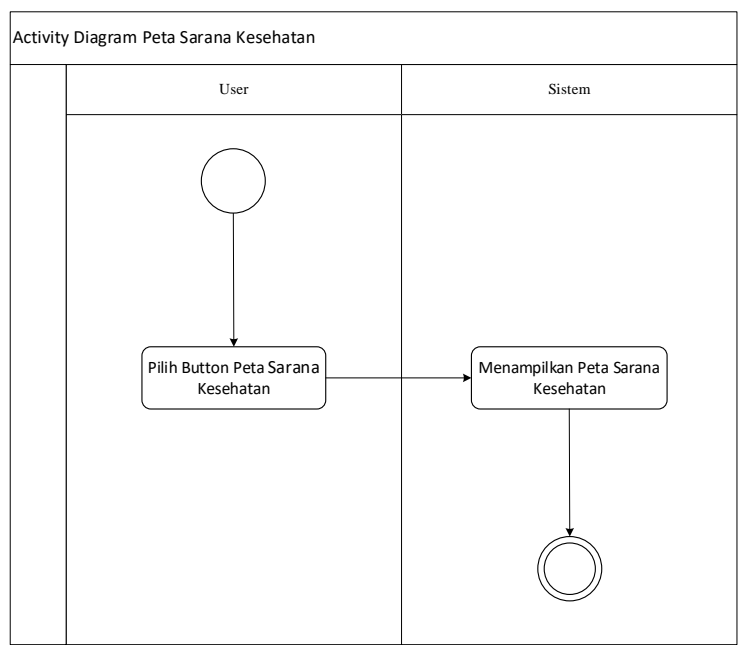

Gambar 12. Activity Diagram Peta Sarana Kesehatan

\subsection{Implementasi Antar Muka}

Implementasi antarmuka adalah hasil visualisasi dari implementasi sistem sesuai rancangan pada tahapan sebelumnya. Berikut ini adalah hasil implementasi dari sistem sebagai berikut :

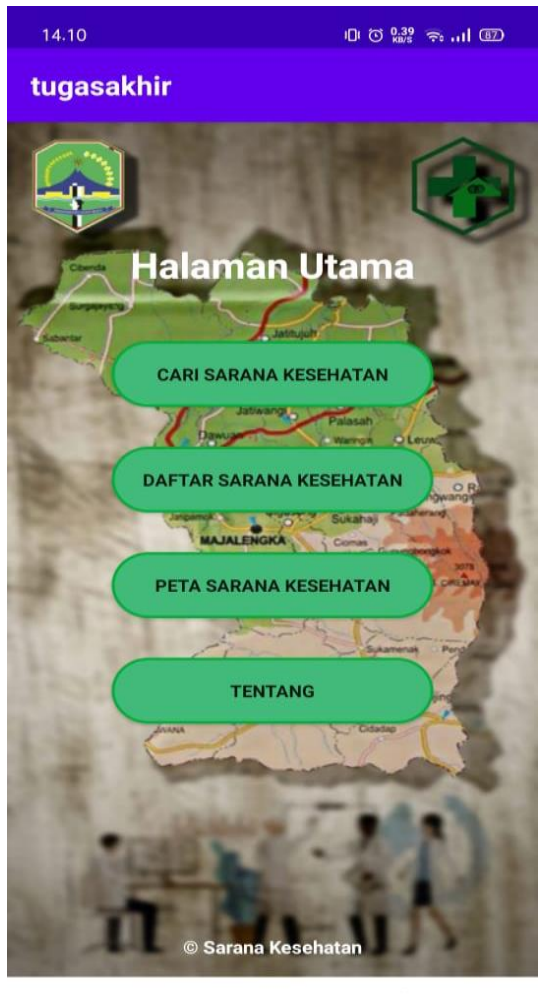

\section{Gambar 13. Halaman Utama}

Halaman menu utama terdapat 4 menu pilihanyaitu, Menu cari sarana kesehatan, daftar sarana kesehatan, peta sarana kesehatan, dan menu tentang. Menu cari sarana kesehatan digunakan untuk mencari sarana kesehatan terdekat, peta sarana kesehatan untuk melihat titik lokasi sarana kesehatan yang ada di Kabupaten Majalengka, menu daftar sarana kesehatan digunakan untuk melihat nama sarana kesehatan yang ada di Kabupaten Majalengkadan menuTentang berisikan biodata pembuat aplikasi. 


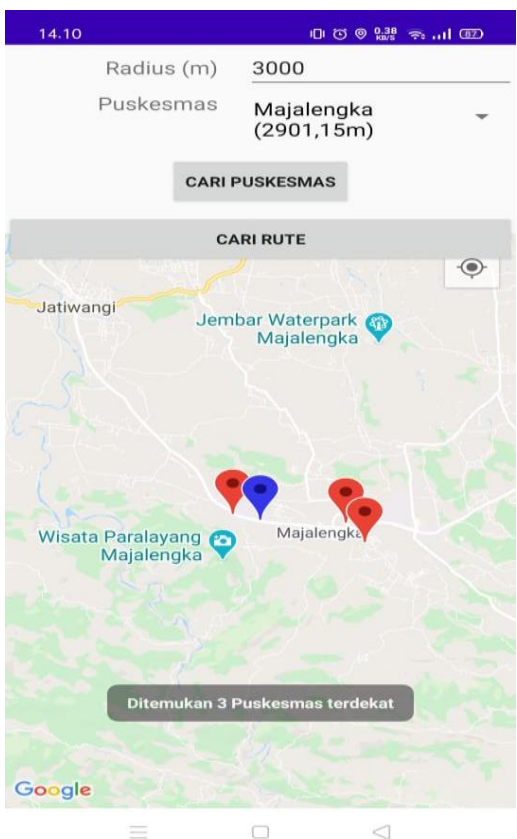

Gambar 14. Cari Sarana Kesehatan

Halaman cari sarana kesehatan digunakan untuk mencari sarana kesehatan terdekat.

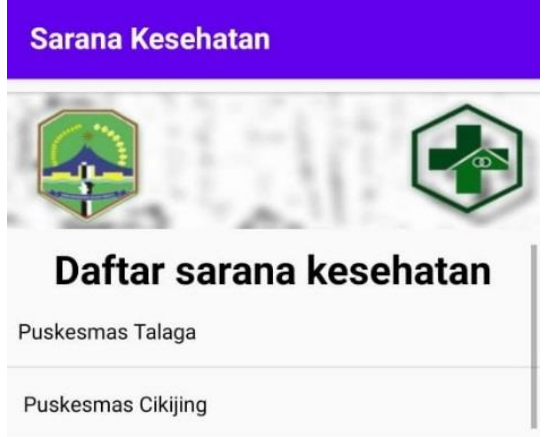

Puskesmas Cingambul

Puskesmas Lemahsugih

Puskesmas Margajaya

Puskesmas Malausma

Puskesmas Bantarujeg

Puskesmas Banjaran

Puskesmas Argapura

Puskesmas Maja

\section{Gambar 15. Tampilan Isi Daftar Sarana Kesehatan}

Tampilan daftar sarana kesehatan digunakan untuk melihat daftar sarana kesehatan yang ada di Kabupaten Majalengka.
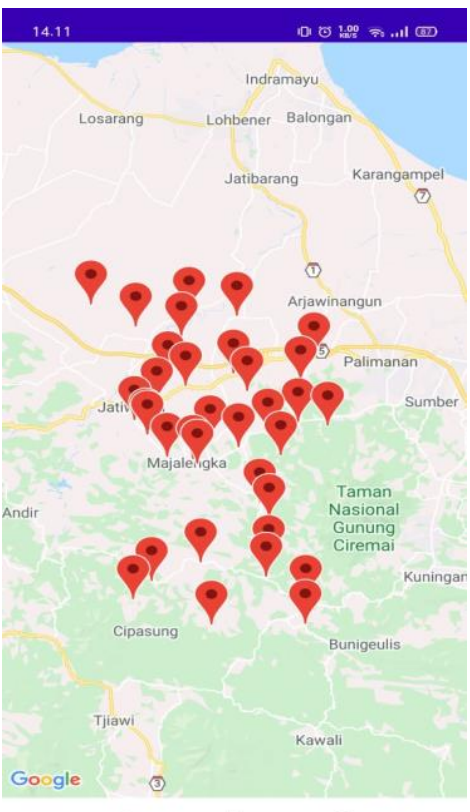

\section{Gambar 16. Tampilan Peta Sarana Kesehatan}

Tampilan peta sarana kesehatan digunakan untuk melihat titik-titik lokasi sarana kesehatan yang ada di Kabupaten Majalengka.

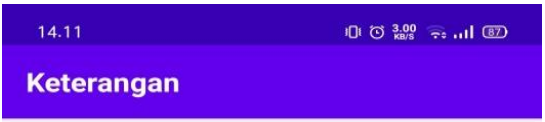

Nama Sarana Kesehatan : Puskesmas Talaga

Alamat : Jl.Jenderal Ahmad Yani,

TalagaWetan, Talaga, 45463

Longitude : 108.311220

Latitude : -6.98331

No Telepon : (0233)319421

Fasilitas :

\section{Gambar 17. Tampilan Keterangan Sarana Kesehatan}

Tampilan keterangan sarana kesehatan digunakan untuk melihat informasi tentang sarana kesehatan yang dipilih. 


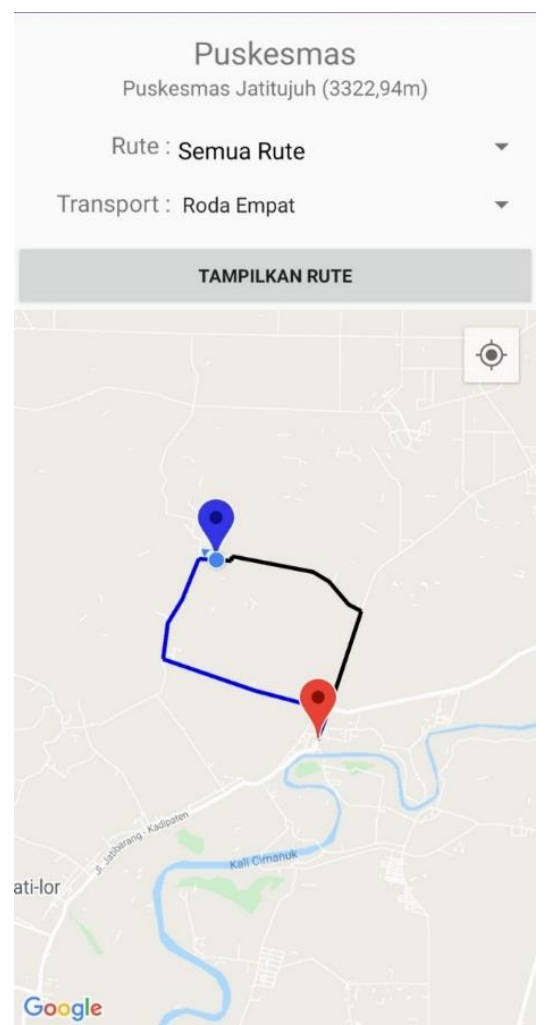

\section{Gambar 18. Tampilan Rute Sarana Kesehatan}

Tampilan rute sarana kesehatan digunakan untuk mencari rute sarana kesehatan yang akan dituju.

\section{KESIMPULAN}

Berdasarkan penelitian yang dilakukan terhadap aplikasi pemetaan sarana kesehatan berbasis android maka dapat kita ambil kesimpulan sebagai berikut:

1. Aplikasi perhitungan aplikasi pemetaan sarana kesehatan berbasis android yang telah dibuat berhasil menampilkan pencarian sarana kesehatan terdekat. Dimana aplikasi ini menyajikan informasi sarana kesehatan yang ada di Majalengka dengan lebih cepat, mudah dan akurat.

2. Fungsi dari aplikasi ini berjalan dengan baik dan sesuai yang mana diharapkan oleh peneliti. Dan telah berhasil menyelesaikan permasalahan pencarian sarana kesehatan terdekat.

\section{PUSTAKA}

Arikunto, S. (2010). Prosedur Penelitian Suatu Pendekatan Praktik. Jakarta:Rineka Cipta.

Fernando, E. (2015). Sistem Informasi Geografis Untuk Pemetaan Tempat Kesehatan Di Jambi. Jurnal Undip.

Lingga Wijaya, H. O. (2017). Perancangan Aplikasi Pemetaan Lokasi Usaha Kecil Menengah (UKM) Di Kota Lubuklinggau Berbasis Goegraphic Information System (GIS) Dan Location Based Service (LBS). Jatisi,
Vol. 3 No. 2.

Maaruf, K. C. (2016). Kecerdasan Buatan Menggunakan Algoritma A-Star Dalam Permainan Ular Tangga. Seminar Nasional Teknologi Informasi dan Multimedia.

Mutsaqov, M. A., Fernando, Y., \& Megawaty, D. A. (2020). PENERAPAN ALGORITMA ASTAR PADA APLIKASI PENCARIAN LOKASI FOTO BERBASIS ANDROID. Jurnal Kelitbangan vol 8. no. 1 .

Nugroho, A., \& Kusuma, A. W. (2018). SISTEM INFORMASI GEOGRAFIS PEMETAAN LOKASI BIRD CONTEST KOTA MALANG BERBASIS ANDROID. Jurnal SISTEMASI, Volume 7, Nomor 3 .

Purnama, S., Megawaty, D. A., \& Fernando, Y. (2018). Penerapan Algoritma A-Star Untuk Penentuan Jarak Terdekat Wisata Kuliner Di Kota Bandar Lampung. Jurnal TEKNOINFO, Vol. 12, No. 1.

Rosa, A., \& Shalahuddin, M. (2018). Rekayasa Perangkat Lunak. Bandung: Informatika Bandung.

Suendri. (2018). Implementasi Diagram UML (Unified Modelling Language) Pada Perancangan Sistem. ALGORITMA: Jurnal Ilmu Komputer dan Informatika.

Syukriyah, Y., Falahah, \& Solihin, H. (2016). Penerapan Algoritma A-Star Untuk Mencari Rute Tercepat Dengan Hambatan. Seminar Nasional Telekomunikasi dan Informatika.

UU Pokok Kesehatan No. 9 tahun 1960, Bab I Pasal 2. (n.d.).

Wibowo, K. M., Kanedi, I., \& Jumadi, J. (2015). Sistem Informasi Geografis (SIG) Menentukan Lokasi Pertambangan Batu Bara Di Provinsi Bengkulu Berbasis Website. Jurnal Media Infotama Vol. 11 No. 1 . 